\title{
Exhumation-Abduction with Violent Death in South Eastern Nigeria from 2007-2011
}

\author{
Martin Anazodo Nnoli ${ }^{1}$, Collins OgbonnaNwabuko ${ }^{2}$, \\ GodwinAbengEbughe ${ }^{3}$, Ayodele Joshua Omotoso ${ }^{3}$ \\ University of Calabar. Dept of Pathology, Calabar. ${ }^{1,3}$ \\ Federal Medical Center, Dept of haematology,Umuahia. ${ }^{2}$
}

\begin{abstract}
Aims \& Objectives: This is to determine the cause of death of victims abducted as to aid justice to the relatives/nation and assist the law enforcement agent to conclude their investigation.

Material and Methods: Eight People were abducted, five of which were men and three were females (two middle aged women and a young girl of about 20 years a grand daughter) that was abducted alongside with the aged grand mother.

Results: Five of the cases were in advanced stages of decomposition but we were able to find the cause of death to be multiple soft tissue and skeletal injuries consequent to gunshots. The rest three though fresh bodies were seen with impressions of strangulation on the neck, ankle and the wrist with single shots either at heart,chest or liver regions.

Conclusion: This has assisted for a truce in mitigating of justice and end to the missing individuals. Correspondence: Dr Martin Nnoli. Consultant Anatomic \& Forensic Pathologist

Keywords: Abduction, Exhumation, Autopsy.
\end{abstract}

\section{Introduction:}

Exhumation or disinterment is the process of removal of remains of previously buried individuals for medico-legal investigations, relocation or other purposes. ${ }^{1}$ These becomes absolutely necessary for a second autopsy to be done to verify the cause of death or identify the deceased. Exhumation may also be done if there are suspected foul play at time of death and later facts emanate as to the real cause of death. In some cases, it may be needed at request of family to recover an object placed in the remains and to rebury the remains at a different location. ${ }^{2}$

Prior to exhumation the information and location of remains need to be verified. The reason for the procedure must be clear and well documented. These will guide the forensic experts as per the specific action to be taken after the remains have been exhumed. This is seen in our own case as the suspected abductors were caught by law enforcement agents-confessional statement made and that facilitated our decision of exhumation. Then, all legal permission and cemetery or the local community authorities sorted. In some nations, exhumations are common, as legal arguments about an accident or an insurance claim; all may require examination of the body to establish medical facts. This is also applicable in systematic exhumation of mass graves which is becoming a frequent occurrence globally. ${ }^{3}$ This is because human remains recovered from mass graves are often semi-skeletonized ,commingling of bodies hence the need for forensic anthropologistare always in the vanguard of forensic experts to use their skills as to recover and proceed to identification of remains from mass graves or large numbers. ${ }^{4}$ Once the burial site has been certified,the process could begin.

The site is secured by grid section if need be,soil samples should be collected from grave site. This is to check for any toxins in the body after the exhumation that have leaked to surrounding ground. These soil samples should be collected from all four sides of the grave;from above and beneath the vault. A soil standard is collected from adjacent area to the grave. ${ }^{2,5,6}$

Importantly, is the willingness and demand of the relatives of the deceased to request to the authorities for exhumation to be done as to ascertain the cause of death. This involves cases where no autopsy were done before burial and further investigations may lead to exhumation. This is performed for the identification of missing or abducted persons. ${ }^{6}$

In all these process the forensic photographer and video recording should be going on;with tape recording of all commentaries for proper documentation at later date of reporting. Once exhumation is completed-casket and body should be sealed with integrity tape and in doing so,integrity of the contents during handling and transportation is ensured. The forensic pathologist/experts put his initials anddate across the tape. It is imperative to note that identification should be done as soon as possible. Positive identification including primary methods of finger print comparison,DNA analysis,dental and medical record comparisons. Other mains like x-ray radiology,facial reconstruction,photographic superimposition and general anthropological assessments could be used but these are all secondary to the primary methods of positive identification. 
The coffin and body should then be moved to secured area for examination and possible second autopsy/tissue recovery. At the new place it is re-photographed to show the integrity of intact coffin. All examination recorded in all available mains. Once all examinations are done body is released for reburial.

This is a holistic approach as morticians, forensic pathologist,law enforcement agent and everyone else with a legitimate interest must be aware of the time arranged. However, if there are possibility of suspected poisoning,samples of soil should be taken as earlier mentioned from all sides of coffin for toxicological examinations. $^{6}$

In our cases, they are known to have been abducted for a while and ransom paid but were all killed and buried to an undisclosed place. Some in a shallow dug grave in a forest and others dumped in a pit covered with little sand.

\section{Materials And Method:}

A cross sectional study of eight exhumation carried out in a south eastern part of Nigeria from 20072011 was analyzed. These are eight in the whole and five were men and the rest three were females of different age group. Two of these are elderly women and a girl of about 20 years old. They were all abducted at different times by their abductors;huge sum of ransom paid to secure their release and despite all these they eventual killed them.

\section{Summary Of Cases:}

In all, the eight cases investigated and exhumed appeared to have a similar history. In each of the cases, they were abducted at different time within the study limit,contact were made to family members/relatives and friends demanding for ransom before they could be released by their respective abductors. In five of the cases within the study unit,they were not able to meet up with the ransom at the time given hence the abductors decided to kill them and bury in a shallow grave. In the rest of three cases, they met the demand but were still killed as the abductors felt the person that came to drop the money happens to have known them.

They relatives of all abducted in all cases made report to the law enforcement agent who went into investigating all the circumstances involved in the so called abduction. These led to arresting of all the culprit at different time within the study limit. In furtherance to all, an inquest was given to the forensic team to carry out all necessary medico-legal examination following the discovery of the sites of each burial. Exhumation with detailed autopsy of bodies recovered was done.

\section{Results:}

In all cases three of the bodies were atadvanced stages of decomposition. However, we were still able to do autopsies and with multiple sites of adipocere on the body there was a clue to possible cause of death. A Probe inserted during autopsy showed an entry and exit end. In these we were able to extract a silver rubber capped bullet used in the execution plus soft tissue injuries in the heart, liver and chest region on the three bodies respectively.

The cause of advanced stages of decomposition we attributed to be due to time/duration of investigation that led to discovery of site of burial. That is the duration taken for the suspects to be caught and information given by them as to assist the enforcement agent might have resulted to the advanced decomposition.

The rest bodies (five of them) were seen on well/shallow grave and were fairly fresh though covered with little sand hence still in fairly good state for easy primary identification. Also is commendable that all suspects were caught in a short period with aid of modern devices acquired by the law enforcement agencies that helped in no small measures in tracking their hide out and consequent investigation of all parties.

LIMITATION OF STUDY: In as much as we know they are victims of abduction;it would have been necessary to test the different soil samples around the coffin as to ascertain any cause/attributed to death. This was not done due to a lot of logistics from family members. Also there wereno sample taken for toxicology as to rule out poison associated death. There is no availability of DNA hence no sample was taken for this purpose.

\section{Discussion:}

The term exhumation,from latin"ex",(meaning out of), and "humus",(meaning ground) is now used to include the disinterment of remains buried lawfully or unlawfully, and the disentombment of those buried above ground in mansoleums.

Exhumation have been performed to permit autopsy or re-autopsy as to determine cause of death for criminal or civil justices. In recent times, there have been increased awareness by international and human rightsorganisations in exhumation of mass graves to identify the dead. More recent developments like DNA technologies have helped in determining paternity and geneology. ${ }^{7}$ 
The merit of exhumation is that more information is available at this time than before the burial or previously autopsied. This is because exhumation autopsy is more focused examination to determine the cause of death as certification is correct and to exclude other possibilities based on new information: Confessional witness statements etc. ${ }^{7}$

This is why exhumation has been the hallmark of forensic investigation. This have been practiced in ancient times despite the reservation of religion of Islam as referred to as Hadith by holy prophet who forbides breaking of bones of dead. ${ }^{8}$

Depending on the state, duration will determine when the body will be positively identified. However, it is imperative that identification be done as soon as possible.

Positive identification should be carried out with DNA analysis, dental and medical record comparison. Other forms of identifications like x-ray radiology, facial reconstruction, photographic superimposition and general anthropological assessments could be used but these are secondary.

However, our own case was quite easy as the relatives/suspects made all possible. The site was made possible by the suspect through the aid of law enforcement officers who caught them at different time during the course of the study; and other identification by physical examination done; and evaluated.

CONCLUSION: The values of exhumation autopsy cannot be over-emphasised in our society especially with the emergence of kidnapping, abduction and other possible causes of violent deaths in our environment. The exhumation of these bodies assisted in bringing civil justices/litigations for drawing to an end the long, protracted issue of the missing individuals .

\section{References:}

[1]. FarharHussainMirza,syedaEzz-e-RukhshanAdil, AkhtaraminMemon. Exhumation-Nuisance to the dead,Justified? Journal of Forensic and Legal Medicine.19 (2012) 337-340.

[2]. H.B.Baldwin,CP May. Exhumation. Encylopedia of Forensic and Legal Medicine,2005,Page 281-284.

[3]. Mark Skinner,DjordjeAlempijeric et al. Guidelines for international forensic Bio-archaelogy Monitors of Mass Grave Exhumations. Forensic science international 134(2003)81-92.

[4]. J Hunter,C.Roberts,A.Martin. Studies in Crime: An introduction to Forensic Archaeology, Batsford, London 1996.

[5]. HumayunM,KhichiZH,ChandH,Khan O et al. Exhumation -A key to provide Justice to victims of Homicide: Situation in Larkana and Sukkur Divisions. J Ayub Med Coll Abbott abad 2010;22(1):168-70

[6]. Richard Shepherd. Simpson's Forensic Medicine 12th edition Chapter 5 Pages 35-6

[7]. Spitz and Fisher's. Exhumation. Medico-legal Investigation of Death. $4^{\text {th }}$ Edition. Chapter 4 Page 174-75.

[8]. Kasule OH. An Islamic Ethico-legal Perspective on Autopsy. Islamic Medical education Resources-05 [internet]. Available from:http//omarkasule-05.tripod.com/id297:htm1\#_edn2;2008. 